\title{
Molecular and cellular aspects of extramedullary manifestations of acute myeloid leukemia
}

\author{
Javad MohammadiasI ${ }^{1}$, Abbas Khosravi², Mohammad Shahjahani ${ }^{2}$, Shirin Azizidoost ${ }^{2}$, Najmaldin Saki² \\ 'Department of Medical Genetics, Faculty of Medicine, Ahvaz Jundishapur University of Medical Sciences, Ahvaz 6135715794, Iran. \\ ${ }^{2}$ Health Research Institute, Research Center of Thalassemia and Hemoglobinopathy, Ahvaz Jundishapur University of Medical Sciences, Ahvaz \\ 6135715794, Iran
}

Correspondence to: Dr. Najmaldin Saki, Health Research Institute, Research Center of Thalassemia and Hemoglobinopathy, Ahvaz Jundishapur University of Medical Sciences, Ahvaz 6135715794, Iran. E-mail: najmaldinsaki@gmail.com

\section{A B S T R A C T}

The myeloid extramedullary tumor is a solid tumor formed by infiltration of immature myeloid cells in various tissues of the body. This tumor is also identified as chloroma or myeloid sarcoma (MS). MS is a manifestation of acute myeloid leukemia (AML) occurring at presentation or during treatment or relapse. MS is associated with multiple chromosomal abnormalities and molecular mutations since patients with these disorders bear a high potential for MS manifestation. There is a high incidence of extramedullary infiltration (EMI) in AML. AML patients with EMI have a worse prognosis than patients without it. Hematopoietic stem cells and leukemic stem cells reside in a special bone marrow microenvironment called niche, which is essential for their normal functions. Cancers are exploited dysfunctional cell-cell and matrix-cell interactions, which convert a normal niche into a neoplastic niche. This study summarizes the current knowledge on the molecular and cellular characteristics of AML with EMI and extramedullary niches in AML patients.

Key words: Acute myeloid leukemia; extramedullary infiltration; niche

\section{INTRODUCTION}

Acute myeloid leukemia (AML) is an aggressive myeloid neoplasm characterized by maturation arrest of myelopoiesis leading to an accumulation of myeloblasts in the blood and bone marrow (BM) ${ }^{[1]} \mathrm{AML}$ is a complex and heterogeneous disease strongly associated with genetic and epigenetic changes in the hematopoietic progenitors. ${ }^{[2]}$ These changes lead to disruption of several signaling pathways that result in increased proliferation, survival and accumulation of leukemic cells. ${ }^{[3]}$

Normal hematopoietic stem cells (HSCs) reside in a specialized area of the BM microenvironment known as niche, which regulates their survival and function. Two distinct niches exist in the BM: Vascular and endosteal/ osteoblastic niche. The vascular niche is localized in close proximity to the osteoblastic niche, at the inner surface of bone cavity with abundant bone-forming osteoblasts. The vascular niche is composed of sinusoidal endothelial cells

\begin{tabular}{|l|l|}
\hline \multicolumn{2}{|c|}{ Access this article online } \\
\hline Quick Response Code: & Website: \\
\hline & www.jcmtjournal.com \\
\hline & \\
\hline
\end{tabular}

lining blood vessels, and it promotes the proliferation and differentiation of short-term HSCs. The endosteal niche includes osteoblasts, osteoclasts, glial non-myelinating Schwann cells and regulatory T-cells, and it is located in the endosteum. The vascular niche contains CXCL12-abundant reticular cells, nestin-positive mesenchymal stem cells and leptin receptor-positive cells. ${ }^{[4]} \mathrm{HSC}$ niches are present in different tissues during development, first in the aortagonad-mesonephros (AGM) region and yolk sac, then in the placenta, fetal liver, spleen and BM. After birth, the BM is the primary site of HSC maintenance and hematopoiesis, but the niche can shift to extramedullary sites in response to hematopoietic stress. ${ }^{[5]}$

AML may present with extramedullary-AML at initial diagnosis or in relapse. Myeloid sarcoma (MS) is defined as an extramedullary mass composed of myeloid blasts occurring in anatomic sites other than BM. ${ }^{[6]}$ Extramedullary

This is an open access article distributed under the terms of the Creative Commons Attribution-NonCommercial-ShareAlike 3.0 License, which allows others to remix, tweak, and build upon the work non-commercially, as long as the author is credited and the new creations are licensed under the identical terms.

For reprints contact: service@oaepublish.com

How to cite this article: Mohammadiasl J, Khosravi A, Shahjahani M Azizidoost S, Saki N. Molecular and cellular aspects of extramedullary manifestations of acute myeloid leukemia. J Cancer Metastasis Treat 2016;2:44-50

Received: 01-02-2015; Accepted: 09-09-2015 
infiltration (EMI) is fairly common in AML patients. In addition, MS has been observed in all age groups, and may occur anywhere in the body. The most common tissues include soft tissues, bone, peritoneum, lymph nodes and gastrointestinal tract. Other occasional sites include male and female urogenital system and central nervous system (CNS). ${ }^{[7]}$ Moreover, several studies have found a worse prognosis in cases of acute leukemia with EMI, which may be explained by a poor response to chemotherapy and disease relapse. ${ }^{[8]}$ Evaluation of the cellular and molecular structures of extramedullary niches, as well as the migration and homing of leukemic cells, may help in designing diagnostic and therapeutic techniques and preventing relapse. However, there is still little information in this regard. The aim of this study was to investigate the characteristics of leukemic cells and the changes in their microenvironment that promote to EMI.

\section{GENETIC AND MOLECULAR FEATURES OF EXTRAMEDULLARY INFILTRATION IN AML}

Extramedullary leukemia (EML) is also called MS, granulocyte sarcoma and chloroma. In the WHO classification, MS is an important subgroup of myeloid neoplasia and acute leukemia. MS may occur simultaneously with, before or after the diagnosis of AML. ${ }^{[9]}$ Genetic mutations and molecular aberrations are an important tool for the evaluation of acute leukemia and assessment of prognosis. However, there is very limited information on the role of genetic mutations in MS. ${ }^{[10]}$ Although the overall incidence of MS in AML has been reported at $1.4-9 \%$, it is particularly high in some subtypes of AML, reaching $18-24 \%$ in AML patients with $\mathrm{t}(8: 21)$ and $25 \%$ in pediatric AML. ${ }^{[1]}$ Other genetic abnormalities diagnosed in EML patients include $\mathrm{t}(15: 17), \mathrm{t}(9: 11), \mathrm{t}(1: 11), \mathrm{t}(8: 17)$, $\operatorname{del}(16 q)$, del(5q), del(20q), monosomy 7, trisomy 4 and trisomy $8 .{ }^{[12]}$ Moreover, according to the French-AmericanBritish classification, some AML types are associated with EML, including M4 and M5 monocytic leukemias and the M2 subtype. ${ }^{[13]}$

The $\mathrm{t}(8: 21)$ has been reported as the most common cytogenetic abnormality associated with EML, occurring both at presentation and upon relapse, and is associated with orbital involvement in infants. ${ }^{[10]} \operatorname{Inv}(16)$ is another abnormality associated with EML; it is rarer than $\mathrm{t}(8: 21)$. According to studies, the bowel may be a target organ in men with inv(16) while breast and ovary tend to develop EML in female patients with inv(16). ${ }^{[14]}$ AML with trisomy 8 is found in nearly 5\% of AML cases with a genetic abnormality. According to a study, trisomy or tetrasomy of chromosome 8 is observed in $35-65 \%$ of AML cases with leukemia cutis as a type of MS. Although confirmation of this relationship requires further evaluation, based on numerous reports, we can suggest that trisomy 8 is a risk factor for skin infiltration in AML. ${ }^{[15]}$
Acute promyelocytic leukemia (APL) is another subtype of AML defined as having a translocation between chromosomes 15 and 17 and generation of promyelocytic leukemia/retinoic acid receptor alpha fusion protein. ${ }^{[16]}$ This fusion protein causes a block at the promyelocytic differentiation stage. ${ }^{[17]}$ APL can occur in extramedullary form, and EMI is responsible for 3-8\% of cases in relapse. The most common target tissues are CNS and skin. ${ }^{[18]}$ Some studies indicate a relationship between 11q23 mixed-lineage leukemia rearrangement (MLLr) and EML. According to some studies, the involvement in this type of cytogenetic abnormalities has been limited to chest and uterus. ${ }^{[19,20]}$ Furthermore, another study suggests a link between MLLr and lymph node involvement. ${ }^{[21]}$ More studies are needed to confirm these observations.

Molecular abnormalities associated with EML have not been systematically defined; however, a well-documented molecular abnormality is a mutation in the nucleophosmin (NPM-1) gene. ${ }^{[12]}$ Nucleolar phosphoprotein or NPM-1 is localized in nuclear foci and is a multifunctional protein expressed in various cells. ${ }^{[22]} N P M-1$ gene mutation is the most common molecular genetic abnormality in AML, particularly AML with normal karyotype. ${ }^{[23]} N P M-1$ is mutated in almost $15 \%$ of cases of MS. ${ }^{[24]}$ In a survey conducted on 89 AML patients, 15 patients (18\%) had extramedullary manifestation at diagnosis, and 13 of them (87\%) had mutated NPM-1..$^{[25]}$

FMS-related tyrosine kinase 3-internal tandem duplication (FLT3-ITD) mutation is observed in $28-34 \%$ of cases of AML with normal cytogenetics. It plays an important role in cell proliferation, survival and differentiation of hematopoietic progenitor cells. ${ }^{[26]}$ Some studies have found an association between FLT3-ITD mutation and EML, so that in one study, $15 \%$ of MS patients have this mutation. ${ }^{[27,28]}$

CD56, a neural cell-adhesion molecule, is expressed in normal, natural killer cells. Aberrant expression of CD56 in AML blasts, particularly AML with translocation $\mathrm{t}(8: 21)$ correlates with a worse prognosis than CD56-negative cases. ${ }^{[29]}$ An association has been described between the expression of CD56 and EMI, especially in lymph nodes (lymphadenopathy). ${ }^{[21,30,31]}$ CD56 gene is in the $11 \mathrm{q} 23.1$ locus. ${ }^{[32]}$ Due to this fact and to the connection between 11q23 mutation and EMI, MLLr is likely associated with aberrant expression of CD56 in EMI. Some case reports and studies support this hypothesis. ${ }^{[20,21,33]}$

Minimal residual disease (MRD) assessment is an important feature of therapy management, especially in cases whose recurrence risk is high. There is not much information on MRD in MS patients, and only one study has evaluated the correlation between continuous detection of AML1MTG8 chimeric transcripts in BM and peripheral blood, and extramedullary relapse in $\mathrm{t}(8: 21)$ AML. ${ }^{[34]}$ 
Available information indicates that the prognosis of EML is poor with short overall survival. ${ }^{[1]}$ In an evaluation, the 5-year survival rate for patients with MS was $21 \%$. Patients treated with chemotherapy showed longer survival than untreated patients. ${ }^{[35]}$ Although the mortality rate of acute leukemia patients has been reduced with the emergence of new therapies, many patients still suffer from refractory disease or relapse, and EMI is one of the main causes of poor prognosis in these patients. ${ }^{[8]}$

\section{EXTRAMEDULLARY NICHE IN AML}

During development, HSCs are initially present in AGM and then migrate into the fetal liver and embryonic bone, which remains the only active site of hematopoiesis in adult life. Movement and homing of HSCs in the BM is associated with CXCL12 chemokine and its receptor CXCR4. ${ }^{[36]}$ Cancer subverts cell-cell and matrix-cell interactions and converts the normal niche to a neoplastic one. ${ }^{[37]}$

ITD-FLT3 mutation, which is common in AML and MS patients, leads to deregulation of CXCR4 in AML leukemic cells since CXCR4 signaling is markedly decreased in patients with ITD-FLT3 compared with patients without it. It is thought that this mutation facilitates the infiltration of leukemic cells into visceral organs by reducing the homing of leukemic cells. ${ }^{[38]}$ Infiltration of leukemic cells in other organs is likely associated with chemokine receptor expression and different adhesion molecules. For example, NCAM1 or CD56, which is associated with a high incidence of MS, is highly expressed in the breast, testicular tissue, ovary and gut. This molecule is responsible for homing of leukemic cells in these tissues. ${ }^{[1]}$ Moreover, AML blasts isolated from skin show a group of specific chemokine receptors including CCR5, CXCR4, CXCR7, and CX3CR1 compared with AML blasts isolated from blood and BM. These cytokinecytokine receptor interactions enable homing and survival of AML blasts in skin [Figure 1]. ${ }^{[39]}$

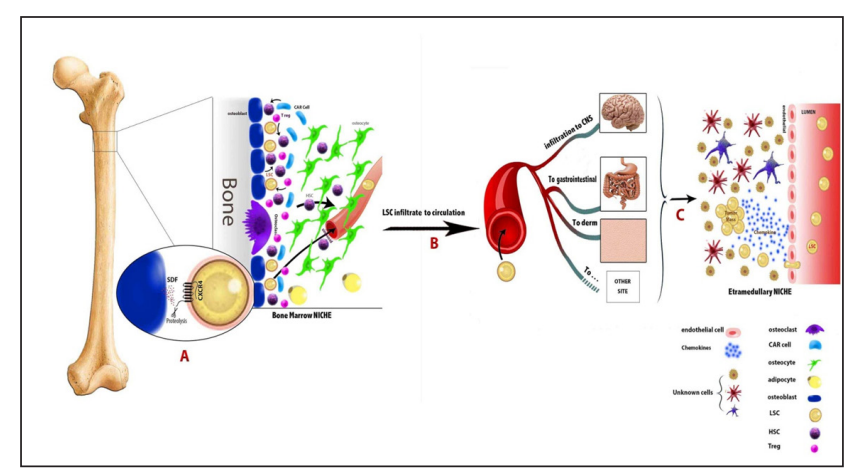

Figure 1: Extramedullary infiltration formation process in acute myeloid leukemia. (A) Within deregulation of LSCs located in BM, cell links with niche will be cut, and then they will enter into the circulation via BM sinusoids; (B) disseminated LSCs circulate in blood vessels and based on their special characteristics, enter specific tissue, like skin; (C) leukemic cells, along with new, distinct niche, initiate new tumor in metastatic tissue. The exact molecular and cellular characteristics have not been defined completely. SDF-1: stromal cell-derived factor 1; BM: bone marrow; LSC: leukemic stem cells; HSC: hematopoietic stem cell; CAR cell: CXCL12-abundant reticular cell
Expression of matrix metalloproteases may contribute to the increased incidence of EMI in some subtypes ofAML. For example, in SHI-1 cells, a highly invasive human acute monocytic leukemia cell line, there is a high expression level of matrix metalloproteinase 2 (MMP-2), membranetype $1 \mathrm{MMP}$ and tissue inhibitor of metalloproteinase, which facilitate cell invasion. ${ }^{[40]}$ Moreover, it has been suggested that the specific binding of MMP-9 via its procatalytic domain to leukocyte surface I domains of beta-2 integrins is essential for precellular proteolysis and migration of AML-derived cells ${ }^{[41]}$ [Table 1].

\section{MICRORNAS' SIGNIFICANCE IN EXTRAMEDULLARY AML}

MicroRNAs (miRNAs) are small, 18-25 nucleotide noncoding RNA molecules, which regulate gene expression by hybridizing to their complementary messenger RNA. Each miRNA has the potential to regulate several different transcripts through partially complementary target sequences. miRNAs participate in cell differentiation, proliferation and carcinogenesis. ${ }^{[56]}$ Several studies have shown that miRNAs play key roles in normal hematopoiesis and various hematological malignancies. Different miRNAs are also known in myelopoiesis and myeloid neoplasias like AML. ${ }^{[57]}$ Functional studies have shown that miRNAs play an important role in the pathogenesis of AML as either oncogenes or tumor suppressors. It has also been shown that distinct miRNA expression signatures are associated with response to chemotherapy and clinical outcomes. ${ }^{[58]}$ Based on our literature and database searches, there has been no study describing miRNA signatures in MS. However, some studies show a link between miRNAs and mutation-induced MS. MiR-100 is aberrantly expressed in a number of cancer cells, including AML cells. Increased expression of miR-100 in AML is associated with maturation block. In vitro studies indicate that increased expression of miR-100 in AML cells inhibits retinoblastoma 1 serine phosphates from human chromosome 3 and causes the release of E2F in addition to increased levels of phosphorylated retinoblastoma. These events induced proliferation and inhibited the differentiation of granulocyte/monocyte cells. ${ }^{[59]}$ In a study performed on 106 pediatric AML patients, it showed that this miRNA was associated with AML with extramedullary manifestation. ${ }^{[60]}$

High expression level of miR-10 family is associated with AML with mutated NPM-1. ${ }^{[25,61]}$ Furthermore, miR-424 in AML patients with NPM-1 mutation was down-modulated. ${ }^{[62]}$ In AML patients with the FLT3-ITD mutation, miR-451 and miR-144 were down-regulated while miR-155 was overexpressed. ${ }^{[63]}$ As previously mentioned, NPM-1 and FLT3-ITD mutations, as well as some other cytogenetic abnormalities, are associated with increased risk of EMI. ${ }^{[25,27,28]}$ In summary, deregulated miRNAs in these disorders can be considered as candidate markers for future studies in MS patients [Table 2]. 
Table 1: Evaluation of AML patients with extramedullary infiltration

\begin{tabular}{|c|c|c|c|c|c|c|c|}
\hline $\begin{array}{l}\text { Age } \\
\text { (years), sex }\end{array}$ & Cytogenetics & $\begin{array}{l}\text { Molecular } \\
\text { test }\end{array}$ & CD markers & $\begin{array}{l}\text { Extramedullary } \\
\text { site }\end{array}$ & Subtype & Prognosis & References \\
\hline 51, female & $\begin{array}{l}\text { 46XX } \\
(50 \%) / 45 X X \text { del } \\
(5)(q 13 q 33),-7, \\
\text { add (15)(q22), } \\
-18\end{array}$ & WT1+ & $\begin{array}{l}\text { MPO+, CD3-, } \\
\text { CD20-, TdT- }\end{array}$ & Genital area & $\begin{array}{l}\text { AML with } \\
\text { multi- } \\
\text { lineage } \\
\text { dysplasia }\end{array}$ & Poor & [42] \\
\hline 16 , female & $\begin{array}{l}\text { PML-RAR at } \\
(15 ; 17)\end{array}$ & & $\begin{array}{l}\text { CD13+(85\%), } \\
\text { CD15+, CD33+, } \\
\text { CD117+, CD34+, } \\
\text { HLA-DR- }\end{array}$ & $\begin{array}{l}\text { Right humerus, } \\
\text { right proximal } \\
\text { femur and distal } \\
\text { tibia }\end{array}$ & APL & & [43] \\
\hline 19 , male & & $\begin{array}{l}11 \mathrm{q} 23 \\
\text { (MLL-AF10) } \\
\text { rearrangement, } \\
\text { low-level }\end{array}$ & $\begin{array}{l}\text { HLA-DR+, } \\
\text { CD4+, CD11c+, } \\
\text { CD13+, CD15+, } \\
\text { CD33+, CD117+, } \\
\text { CD56+, CD45 }\end{array}$ & Pulmonary & M5 & & [44] \\
\hline & & $\begin{array}{l}\text { FLT3 } \\
\text { inhibition }\end{array}$ & & & & & \\
\hline 42 , female & $\begin{array}{l}\mathrm{t}(8 ; 21)-R U N X 1- \\
\text { RUNX1T1 }\end{array}$ & FLT3-ITD & $\begin{array}{l}\text { MPO+, CD34+, } \\
\text { Ki67 (60-70\%) }\end{array}$ & Auditory canal & M2 & $\begin{array}{l}\text { Second } \\
\text { morphologic } \\
\text { CR }\end{array}$ & [45] \\
\hline 29 , female & $\begin{array}{l}47, \mathrm{XX},+8, \mathrm{t} \\
(9 ; 11)(\mathrm{p} 22 ; \mathrm{q} 23)\end{array}$ & $\begin{array}{l}\text { MLL-AF9 } \\
\text { fusion gene }\end{array}$ & $\begin{array}{l}\text { CD117+, CD33+, } \\
\text { CD38+, CD15+, } \\
\text { CD64+, CD4+, } \\
\text { CD56+ }\end{array}$ & $\begin{array}{l}\text { Left and right } \\
\text { breast }\end{array}$ & M4 & $\mathrm{CR}$ & [20] \\
\hline 28 , female & $\begin{array}{l}\text { No overt } \\
\text { cytogenetic } \\
\text { aberration was } \\
\text { shown }\end{array}$ & $\begin{array}{l}\text { MLL-AF9 } \\
\text { fusion gene }\end{array}$ & $\begin{array}{l}\text { CD117+, CD13+, } \\
\text { CD33+, CD34+, } \\
\text { CD38+, MPO+, } \\
\text { HLA-DR+ }\end{array}$ & Left breast & M4 & $\mathrm{CR}$ & [20] \\
\hline 12 , female & $\mathrm{t}(9 ; 11)(\mathrm{p} 22 ; \mathrm{q} 23)$ & $\begin{array}{l}M L L \text { gene } \\
\text { rearrangement }\end{array}$ & $\begin{array}{l}\text { CD45+, CD33+, } \\
\text { CD4+, } \\
\text { alpha-1- } \\
\text { antitrypsin+, } \\
\text { muramidase+ }\end{array}$ & $\begin{array}{l}\text { Intra-abdominal } \\
\text { and presacral }\end{array}$ & M5 & $\mathrm{CR}$ & [46] \\
\hline 15 , female & & & $\begin{array}{l}\text { HLA-DR+, } \\
\text { CD33+, CD15+, } \\
\text { CD4+, CD11c+, } \\
\text { CD11b+, CD9+, } \\
\text { CD7+, CD56+, } \\
\text { CD14+ }\end{array}$ & Abdomen & M5a & Poor & [47] \\
\hline $\begin{array}{l}\text { 3-month, } \\
\text { female }\end{array}$ & $\begin{array}{l}\text { normal female } \\
\text { karyotype - } \\
\mathrm{t}(9 ; 11)(\mathrm{p} 22 ; \mathrm{q} 23)\end{array}$ & $\begin{array}{l}M L L \text { gene } \\
\text { rearrangement }\end{array}$ & $\begin{array}{l}\text { CD45+, CD33+, } \\
\text { CD117+, CD4+, } \\
\text { CD1a+ }\end{array}$ & Skin & M5 & CR & [47] \\
\hline 10 , male & $\begin{array}{l}45, X,-Y, \text { del }(2) \\
\text { (p21), t( } 8 ; 21) \\
\text { (q22;q22) }\end{array}$ & & $\begin{array}{l}\text { CD13+, CD34+, } \\
\text { CD33+, MPO+, } \\
\text { HLA-DR+ }\end{array}$ & Appendix & M2 & $\mathrm{CR}$ & [48] \\
\hline 38 , female & $\mathrm{t}(6 ; 21)$ & & $\begin{array}{l}\text { CD13+, CD33+, } \\
\text { CD34+, CD15+, } \\
\text { CD117+, CD64+, } \\
\text { CD65+, MPO+, } \\
\text { CD56+ }\end{array}$ & Gastric & M4 & Poor & {$[33]$} \\
\hline 57 , male & $\begin{array}{l}47, X Y,+8, \\
\text { t(9;11)(p22; q23) }\end{array}$ & $\begin{array}{l}11 \mathrm{q} 23 \text {, } \\
\text { tetrasomy } 8\end{array}$ & $\begin{array}{l}\mathrm{CD} 4+, \mathrm{CD} 13+ \\
\text { CD16+, CD33+, } \\
\text { CD56+ and }\end{array}$ & Forearm and thigh & M5a & $\begin{array}{l}\text { No relapse } \\
\text { during } \\
\text { chemotherapy }\end{array}$ & [33] \\
\hline & & & HLA-DR+ & & & & \\
\hline $\begin{array}{l}69 \text {, temale } \\
47 \text {, male }\end{array}$ & $\mathrm{t}(8 ; 17), \mathrm{t}(17 ; 17)$ & & $\begin{array}{l}\text { MPO+, CD } 43+ \\
\text { CD33+, CD 34+, } \\
\text { CD117+ }\end{array}$ & $\begin{array}{l}\text { Eye } \\
\text { Pancreas }\end{array}$ & $\begin{array}{l}\text { M1 } \\
\text { M2 }\end{array}$ & Poor & $\begin{array}{l}{[49]} \\
50]\end{array}$ \\
\hline 1 , male & $\mathrm{t}(15: 17)$ & PML-RARA & $\begin{array}{l}\text { CD } 33+, \text { CD65+, } \\
\text { MPO+ }\end{array}$ & Mandible & APL & & [51] \\
\hline 13 , female & $\begin{array}{l}47, X X,+21 \text { and } \\
46, \operatorname{del}(x)(q 22)\end{array}$ & & $\begin{array}{l}\text { CD45+, CD117+, } \\
\text { CD34+, CD43+, } \\
\text { CD68+ }\end{array}$ & Cardiac & M5 & Poor & [52] \\
\hline
\end{tabular}


Table 1: Contd...

\begin{tabular}{|c|c|c|c|c|c|c|c|}
\hline \multicolumn{2}{|c|}{$\begin{array}{l}\text { Age (years), Cytogenetics } \\
\text { sex }\end{array}$} & $\begin{array}{l}\text { Molecular } \\
\text { test }\end{array}$ & CD markers & $\begin{array}{l}\text { Extramedullary } \\
\text { site }\end{array}$ & Subtype & Prognosis & References \\
\hline & $\begin{array}{l}46, X Y \text {, dup (1) (q21; q32) in } \\
2 / 20 \text { cells and } 46, X Y 18 / 20 \text { cell }\end{array}$ & $\begin{array}{l}\text { FLT3-ITD } \\
\text { mutation }\end{array}$ & CD34+, MPO+, CD25+ & Epidural & M2 & & [53] \\
\hline 64 , male & Trisomy 8 & & $\begin{array}{l}\mathrm{CD} 45+, \mathrm{CD} 68+(\mathrm{KP}-1), \\
\mathrm{CD} 4+, \mathrm{CD} 56+\end{array}$ & Skin & M5 & & [15] \\
\hline 24 , male & $46, \mathrm{XY}$ and $\mathrm{t}(8 ; 21)(\mathrm{q} 22 ; \mathrm{q} 22)$ & & $\mathrm{MPO}+, \mathrm{CD} 56+$ & Stomach & M2 & & [54] \\
\hline 47 , female & Deletion 17q21 & & CD43+, CD68+, CD56- & Eye & M4 & Poor & [55] \\
\hline
\end{tabular}

MPO: myeloperoxidase; AML: acute myeloid leukemia; APL: acute promeylocytic leukemia; CR: complete remission; FLT3-ITD: FMSrelated tyrosine kinase 3-internal tandem duplication; MLL: mixed-lineage leukemia; PML-RARA: promyelocytic leukemia/retinoic acid receptor alpha; HLA-DR: human leukocyte antigens-DR; TdT: terminal deoxynucleotidyl transferase

Table 2: MiR changes in AML with abnormalities associated with prevalence of myeloid sarcoma

\begin{tabular}{|c|c|c|c|}
\hline Abnormality & Down-regulate & Up-regulate & References \\
\hline $\begin{array}{l}11 \mathrm{q} 23, \mathrm{MLL} \\
\text { rearrangement }\end{array}$ & $\begin{array}{l}\text { miR-34b, miR-15a, miR-29a, miR-29c, miR-372, } \\
\text { miR-30a, miR-29b, miR-30e, miR-196a, mir196b } \\
\text { let-7f, miR-102, miR-331, miR-299, miR-193 }\end{array}$ & $\begin{array}{l}\text { miR-326, miR-219, miR-194, miR-301, } \\
\text { miR-324, miR-339, miR-99b, miR-328, miR150, } \\
\text { miR-17-92 cluster }\end{array}$ & [64-66] \\
\hline FIT3-ITD & $\operatorname{miR}-451, \operatorname{miR}-144$ & $\begin{array}{l}\text { miR-155 (3.1-fold), miR-10a ( } 2.5 \text {-fold }) \text { and } \\
\text { miR-10b (2.27-fold) }\end{array}$ & {$[63,65]$} \\
\hline NPM-1 & $\operatorname{miR}-424$ & $\operatorname{miR}-10$ & {$[61,62]$} \\
\hline APL & $\operatorname{miR}-181 b$ & $\begin{array}{l}\text { miR-15a, miR-15b, miR-16-1, let-7a-3, let-7c, } \\
\text { let-7d, miR-223, miR-342 and miR-107, miR125b }\end{array}$ & {$[67,68]$} \\
\hline$+8 \mathrm{AML}$ & miR-496, miR-493 & miR-34b, miR370, miR107, miR-342-3p, miR-96 & [69] \\
\hline
\end{tabular}

AML: acute myeloid leukemia; APL: acute promyelocytic leukemia; NPM-1: nucleophosmin-1; MLL: mixed-lineage leukemia

\section{CONCLUSION}

EMI is a relatively common manifestation of AML, with increased incidence in specific subtypes. ${ }^{[7]}$ Despite advances in the diagnosis and treatment of myeloid leukemias, there is insufficient information on the diagnosis, treatment and pathogenesis of EML. ${ }^{[38]}$ Molecular and cellular studies of EML cases, as well as evaluation of the differences between AML patients with and without EMI, have revealed some features of EML. Elucidating the relationship between genetic abnormalities and sites prone to infiltration may contribute to the prevention and early detection of EML in target tissues. In many cases, MS is misdiagnosed at first, with the most common alternative diagnoses being lymphoma, melanoma, extramedullary hematopoiesis and inflammation. Given the aggressive nature of MS, early diagnosis with sensitive and specific tests is vital to these patients. ${ }^{[9]}$ Available information suggests that ITD-FLT3 mutations, which are prevalent in patients with EML, may play an important role in the pathogenesis of disease. Therefore, ITD-FLT3 mutation scan should be evaluated as a diagnostic and prognostic factor in patients. Moreover, NPM-1 mutation, which also has a high prevalence in EML, should be evaluated as a prognostic test.

According to case report studies, common CD markers in EML include CD13, CD33, CD34, CD117, myeloperoxidase (MPO), CD56 and CD68; these should be considered in immunophenotype assessment of the disease [Table 1]. In a study conducted on MS patients, similar results were indicated, and CD68/KP1 was the most common positive marker in $100 \%$ of patients. Other markers, in order of positive frequency, were: MPO (83.6\%), CD117 (80.4\%), CD99 (54.3\%), CD68/ PG-M1 (51\%), CD34 (43.4\%), terminal deoxynucleotidyl transferase (31.5\%), CD56(13\%), CD61 (2.2\%), CD30 (2.2\%) and CD4 (1.1\%). ${ }^{[70]}$ These data can be useful to develop a diagnostic immunophenotyping panel for MS patients. Allogeneic hematopoietic stem cell transplantation (HSCT) is increasingly used as treatment procedure for AML patients, but there are no standard procedures for EML therapy. Furthermore, HSCT not only is not an effective procedure for EML, but it can also increase the risk of EML relapse in AML patients. ${ }^{[71]}$ Studies reviewed in this article suggest that cases of AML that have blasts with relatively specific characteristics have a highrisk for non-hematopoietic tissue infiltration. These features may be very helpful in distinguishing patients susceptible to EMI. Further studies are needed to develop diagnostic and therapeutic standards for patients with EMI as well as sensitive and specific prognostic biomarkers.

\section{Acknowledgments}

We wish to thank all our colleagues in Shafa Hospital and Allied Health Sciences School, Ahvaz Jundishapur University of Medical Sciences.

\section{Financial support and sponsorship Nil.}

\section{Conflicts of interest}

There are no conflicts of interest. 


\section{REFERENCES}

1. Schiller GJ. Evolving treatment strategies in patients with high-risk acute myeloid leukemia. Leuk Lymphoma 2014;55:2438-48.

2. Meyer SC, Levine RL. Translational implications of somatic genomics in acute myeloid leukaemia. Lancet Oncol 2014;15:e382-94.

3. Arceci RJ, Berman JN, Meshinchi S. Acute myeloid leukemia. In: Arceci GD, editor. Cancer Genomics. Boston: Academic Press; 2014. p. $283-300$

4. Tabe Y, Konopleva M. Advances in understanding the leukaemia microenvironment. Br J Haematol 2014;164:767-78.

5. Morrison SJ, Scadden DT. The bone marrow niche for haematopoietic stem cells. Nature 2014;505:327-34.

6. Stölzel F, Röllig C, Radke J, Mohr B, Platzbecker U, Bornhäuser M, Paulus T, Ehninger G, Zöphel K, Schaich M. ${ }^{18}$ F-FDG-PET/CT for detection of extramedullary acute myeloid leukemia. Haematologica 2011;96:1552-6.

7. Yilmaz AF, Saydam G, Sahin F, Baran Y. Granulocytic sarcoma: a systematic review. Am J Blood Res 2013;3:265-70.

8. Jiang L, Yu G, Meng W, Wang Z, Meng F, Ma W. Overexpression of amyloid precursor protein in acute myeloid leukemia enhances extramedullary infiltration by MMP-2. Tumor Biol 2013;34:629-36.

9. Avni B, Koren-Michowitz M. Myeloid sarcoma: current approach and therapeutic options. Ther Adv Hematol 2011;2:309-16.

10. Bakst RL, Tallman MS, Douer D, Yahalom J. How I treat extramedullary acute myeloid leukemia. Blood 2011;118:3785-93.

11. Tirado CA, Chen W, Valdez F, Karandikar N, Arbini A, Acevedo I, Garcia R, Davila O, Smart RL, Matthews E, Kirk A, Collins $\mathrm{RH}$. Unusual presentation of myeloid sarcoma in a case of acute promyelocytic leukemia with a cryptic PML-RARA rearrangement involving multiple sites including the atrium. Cancer Genet Cytogenet 2010;200:47-53.

12. Ohanian M, Faderl S, Ravandi F, Pemmaraju N, Garcia-Manero G, Cortes J, Estrov Z. Is acute myeloid leukemia a liquid tumor? Int $J$ Cancer 2013;133:534-43.

13. Ganzel C, Douer D. Extramedullary disease in APL: a real phenomenon to contend with or not? Best Pract Res Clin Haematol 2014;27:63-8.

14. Zhang XH, Zhang R, Li Y. Granulocytic sarcoma of abdomen in acute myeloid leukemia patient with inv(16) and $\mathrm{t}(6 ; 17)$ abnormal chromosome: case report and review of literature. Leuk Res 2010;34:958-61.

15. Shvartsbeyn M, Meehan SM, Gu P, Nierodzik ML, Perle MA. Trisomy 8 in myeloid leukemia cutis confirmed by fluorescence in situ hybridization analysis. J Cutan Pathol 2012;39:1026-9.

16. Scaglioni PP, Pandolfi PP. The theory of APL revisited. Curr Top Microbiol Immunol 2007;313:85-100.

17. Zeng C, Xu Y, Xu L, Yu X, Cheng J, Yang L, Chen S, Li Y. Inhibition of long non-coding RNA NEAT1 impairs myeloid differentiation in acute promyelocytic leukemia cells. BMC cancer 2014;14:693.

18. Naina HV, Levitt D, Vusirikala M, Anderson LD Jr, Scaglioni PP, Kirk A, Collins RH Jr. Successful treatment of relapsed and refractory extramedullary acute promyelocytic leukemia with tamibarotene. $J$ Clin Oncol 2011;29:e534-6.

19. De Braekeleer E, Meyer C, Douet-Guilbert N, Basinko A, Le Bris MJ, Morel F, Berthou C, Marschalek R, Férec C, De Braekeleer M. Identification of MLL partner genes in 27 patients with acute leukemia from a single cytogenetic laboratory. Mol Oncol 2011;5:555-63.

20. Wu B, Li F, Zou S. MLL-AF9 rearrangement in myeloid sarcomas involving the breast. Ann Hematol 2014;93:709-10.

21. Chang H, Brandwein J, Yi QL, Chun K, Patterson B, Brien B. Extramedullary infiltrates of AML are associated with CD56 expression, 11q23 abnormalities and inferior clinical outcome. Leuk Res 2004;28:1007-11.

22. Gallo A, Lo Sterzo C, Mori M, Di Matteo A, Bertini I, Banci L, Brunori M, Federici L. Structure of nucleophosmin DNA-binding domain and analysis of its complex with a G-quadruplex sequence from the c-MYC promoter. J Biol Chem 2012;287:26539-48.

23. Chen HY, Lu QY. Research on NPM1 gene mutations in acute myeloid leukemia. Zhongguo Shi Yan Xue Ye Xue Za Zhi 2013;21:258-62.
24. Falini B, Martelli MP, Bolli N, Sportoletti P, Liso A, Tiacci E, Haferlach T. Acute myeloid leukemia with mutated nucleophosmin (NPM1): is it a distinct entity? Blood 2011;117:1109-20.

25. Ovcharenko D, Stölzel F, Poitz D, Fierro F, Schaich M, Neubauer A, Kelnar K, Davison T, Müller-Tidow C, Thiede C, Bornhäuser M, Ehninger G, Brown D, Illmer T. miR-10a overexpression is associated with NPM1 mutations and MDM4 downregulation in intermediaterisk acute myeloid leukemia. Exp Hematol 2011;39:1030-42.e7.

26. Port M, Böttcher M, Thol F, Ganser A, Schlenk R, Wasem J, Neumann A, Pouryamout L. Prognostic significance of FLT3 internal tandem duplication, nucleophosmin 1, and CEBPA gene mutations for acute myeloid leukemia patients with normal karyotype and younger than 60 years: a systematic review and meta-analysis. Ann Hematol 2014;93:1279-86.

27. Ansari-Lari MA, Yang CF, Tinawi-Aljundi R, Cooper L, Long P, Allan RH, Borowitz MJ, Berg KD, Murphy KM. FLT3 mutations in myeloid sarcoma. Br J Haematol 2004;126:785-91.

28. Colovic N, Tomin D, Vidovic A, Tosic N, Atkinson HD, Colovic MD. Central nervous system relapse in CD56+, FLT3/ITD+promyelocytic leukemia. Med Oncol 2012;29:260-2.

29. Muroi K, Fujiwara S, Tatara R, Sugimoto M, Yamamoto C, Uehara E, Meguro A, Hatano K, Okazuka K, Oh I, Ohmine K, Suzuki T, Mori M, Nagai T, Ozawa K. CD56 expression in normal immature granulocytes after allogeneic hematopoietic stem cell transplantation. J Clin Exp Hematopathol 2013;53:247-50.

30. Yang LL, Gan SL, Liu YF, Zhang QT, Li T, Ma J, Sun H. Clinical characteristics of CD56(+) patients with acute monocytic leukemia and their prognostic significance. Zhongguo Shi Yan Xue Ye Xue Za Zhi 2013;21:596-600.

31. Breccia M, De Propris MS, Minotti C, Stefanizzi C, Raponi S, Colafigli G, Latagliata R, Guarini A, Foà R. Aberrant phenotypic expression of CD15 and CD56 identifies poor prognostic acute promyelocytic leukemia patients. Leuk Res 2014;38:194-7.

32. Mitteldorf C, Bertsch HP, Baumgart M, Haase D, Wulf G, Schön MP, Rosenwald A, Neumann C, Kaune KM. Lacking CD56 expression in a relapsing cutaneous blastic plasmacytoid dendritic cell neoplasm after allogeneic bone marrow transplantation: FISH analysis revealed loss of 11q. J Eur Acad Dermatol Venereol 2011;25:1225-9.

33. Takahashi T, Tsukuda H, Kimura H, Yoshimoto M, Tsujisaki M. Extramedullary relapse of AML with $\mathrm{t}(9 ; 11)$ (p22;q23) associated with clonal evolution from trisomy 8 into tetrasomy 8 . Intern Med 2010;49:447-51.

34. Tamaki H, Yoshihara S, Fujioka T, Kawakami M, Oka Y, Ogawa H. Molecular detection of AML1-MTG8-positive cells in peripheral blood from a patient with isolated extramedullary relapse of $t(8 ; 21)$ acute myeloid leukemia. Leukemia 2009;23:424-6.

35. Lan TY, Lin DT, Tien HF, Yang RS, Chen CY, Wu K. Prognostic factors of treatment outcomes in patients with granulocytic sarcoma. Acta Haematol 2009;122:238-46.

36. Calvi LM, Link DC. Cellular complexity of the bone marrow hematopoietic stem cell niche. Calcif Tissue Int 2014;94:112-24

37. Saki N, Abroun S, Farshdousti Hagh M, Asgharei F. Neoplastic bone marrow niche: hematopoietic and mesenchymal stem cells. Cell $J$ 2011;13:131-6.

38. Fukuda S, Onishi C, Pelus LM. Trafficking of acute leukemia cells-chemokine receptor pathways that modulate leukemia cell dissemination. In: Antica M, editor. Acute Leukemia: The Scientist's Perspective and Challenge. Rijeka: InTech; 2011.

39. Faaij CM, Willemze AJ, Révész T, Balzarolo M, Tensen CP, Hoogeboom M, Vermeer MH, van Wering E, Zwaan CM, Kaspers GJ, Story C, an Halteren AG, Vossen JM, Egeler RM, an Tol MJ, Annels NE. Chemokine/chemokine receptor interactions in extramedullary leukaemia of the skin in childhood AML: differential roles for CCR2, CCR5, CXCR4 and CXCR7. Pediatr Blood Cancer 2010;55:344-8.

40. Wang C, Chen Z, Li Z, Cen J. The essential roles of matrix metalloproteinase-2, membrane type 1 metalloproteinase and tissue inhibitor of metalloproteinase- 2 in the invasive capacity of acute monocytic leukemia SHI-1 cells. Leuk Res 2010;34:1083-90. 
41. Stefanidakis M, Karjalainen K, Jaalouk DE, Gahmberg CG, O'Brien S, Pasqualini R, Arap W, Koivunen E. Role of leukemia cell invadosome in extramedullary infiltration. Blood 2009;114:3008-17.

42. Pulgar F, Vélez D, Valdeolivas N, García J, Cabrera A, Pericet L, Trasobares L, Medina S, García M. Post-bone-marrow-transplant leukemia cutis. Dermatol Online J 2013;19:6.

43. Worch J, Ritter J, Frühwald MC. Presentation of acute promyelocytic leukemia as granulocytic sarcoma. Pediatr Blood Cancer 2008;50:657-60.

44. Hoffman LM, Gore L, Maloney KW. Pulmonary presentation of relapsed acute myeloid leukemia. J Pediatr Hematol Oncol 2014;36:228-30.

45. Di Veroli A, Micarelli A, Cefalo M, Ceresoli E, Nasso D, Cicconi L, Mauramati S, Ottaviani F, Venditti A, Amadori S. Recurrence of at $(8 ; 21)$-positive acute myeloid leukemia in the form of a granulocytic sarcoma involving cranial bones: a diagnostic and therapeutic challenge. Case Rep Hematol 2013;2013:245395.

46. Johansson B, Fioretos T, Kullendorff CM, Wiebe T, Békássy AN, Garwicz S, Forestier E, Roos G, Akerman M, Mitelman F, Billström R. Granulocytic sarcomas in body cavities in childhood acute myeloid leukemias with 11q23/MLL rearrangements. Genes Chromosomes Cancer 2000;27:136-42.

47. Lin $\mathrm{CH}, \mathrm{Wu} \mathrm{KH}$, Lin WC, Tsai JD, Peng CT, Chen AC. Granulocytic sarcoma of the colon in a child with acute myeloid leukemia presenting as hematochezia. J Pediatr Hematol Oncol 2008;30:981-3

48. Choi ER, Ko YH, Kim SJ, Jang JH, Kim K, Kang WK, Jung CW, Kim DH. Gastric recurrence of extramedullary granulocytic sarcoma after allogeneic stem cell transplantation for acute myeloid leukemia. $J$ Clin Oncol 2010;28:e54-5.

49. Méndez-Cepeda P, Millán-Rodríguez AC, Dios E, Alvarez C, Sevillano C. Conjunctival myeloid sarcoma in acute myeloblastic leukemia-M1. Arch Soc Esp Oftalmol 2012;87:79-81.

50. Tabriz N, Tannapfel A, Griesinger F, Weyhe D. Chloroma of pancreas-initial manifestation of a secondary leukemia after stem cell transplantation case report and review of the literature. J Gastrointest Surg 2013;17:1331-5

51. Yamashita Y, Isomura N, Hamasaki Y, Goto M. Case of pediatric acute promyelocytic leukemia presenting as extramedullary tumor of the mandible. Head Neck 2013;35:E310-3

52. Cash T, Becton D, Mian A. Cardiac myeloid sarcoma: a case report and review of literature. J Pediatr Hematol Oncol 2011;33:e330-2.

53. Isshiki Y, Ohwada C, Togasaki E, Shimizu R, Hasegawa N, Yamazaki A, Sugita Y, Kawaguchi T, Tsukamoto S, Sakai S, Takeda Y, Takeuchi M, Sakaida E, Shimizu N, Ota S, Yokote K, Iseki T, Nakaseko C. Acute myeloid leukemia concurrent with spinal epidural extramedullary myeloid sarcoma accompanied by a high CD25 expression and the FLT3-ITD mutation. Intern Med 2014;53:1159-64.

54. Ando T, Mitani N, Matsui K, Yamashita K, Nomiyama J, Tsuru M, Yujiri T, Tanizawa Y. Recurrent extramedullary relapse of acute myelogenous leukemia after allogeneic hematopoietic stem cell transplantation in a patient with the chromosomal abnormality $\mathrm{t}(8 ; 21)$ and CD56-positivity. Int J Hematol 2009;90:374-7.

55. Kiratli H, Demiroğlu H, Emeç S. Ocular relapse in acute myeloid leukemia (M4) with normal bone marrow. Int Ophthalmol 2009;29:243-5.

56. Svensson AM, Hu Y. Molecular diagnostics in adult acute myeloid leukemia. North Am J Med Sci 2012;5:29-37.

57. Undi RB, Kandi R, Gutti RK. MicroRNAs as haematopoiesis regulators. Adv Hematol 2013;2013:695754.

58. Ranganathan P, Garzon R. Clinical implications of MicroRNAs in AML. In: Andreeff M, editor. Targeted Therapy of Acute Myeloid Leukemia. Berlin: Springer; 2015. p. 699-705.

59. Zheng YS, Zhang H, Zhang XJ, Feng DD, Luo XQ, Zeng CW, Lin KY, Zhou H, Qu LH, Zhang P, Chen YQ. MiR-100 regulates cell differentiation and survival by targeting RBSP3, a phosphatase-like tumor suppressor in acute myeloid leukemia. Oncogene 2011;31:80-92.

60. Bai J, Guo A, Hong Z, Kuai W. Upregulation of microRNA-100 predicts poor prognosis in patients with pediatric acute myeloid leukemia. Onco Targets Ther 2012;5:213-9.

61. Havelange V, Ranganathan P, Geyer S, Nicolet D, Huang X, Yu X, Volinia S, Kornblau SM, Andreeff M, Croce CM, Marcucci G, Bloomfield CD, Garzon R. Implications of the miR-10 family in chemotherapy response of NPM1-mutated AML. Blood 2014;123:2412-5.

62. Faraoni I, Laterza S, Ardiri D, Ciardi C, Fazi F, Lo-Coco F. MiR-424 and miR-155 deregulated expression in cytogenetically normal acute myeloid leukaemia: correlation with NPM1 and FLT3 mutation status. J Hematol Oncol 2012;5:26.

63. Whitman SP, Maharry K, Radmacher MD, Becker H, Mrózek K, Margeson D, Holland KB, Wu YZ, Schwind S, Metzeler KH, Wen J, Baer MR, Powell BL, Carter TH, Kolitz JE, Wetzler M, Moore JO, Stone RM, Carroll AJ, Larson RA, Caligiuri MA, Marcucci G, Bloomfield CD. FLT3 internal tandem duplication associates with adverse outcome and gene-and microRNA-expression signatures in patients 60 years of age or older with primary cytogenetically normal acute myeloid leukemia: a Cancer and Leukemia Group B study. Blood 2010;116:3622-6.

64. Mi S, Li Z, Chen P, He C, Cao D, Elkahloun A, Lu J, Pelloso LA, Wunderlich M, Huang H, Luo RT, Sun M, He M, Neilly MB, ZeleznikLe NJ, Thirman MJ, Mulloy JC, Liu PP, Rowley JD, Chen J. Aberrant overexpression and function of the miR-17-92 cluster in MLL-rearranged acute leukemia. Proc Natl Acad Sci U S A 2010;107:3710-5.

65. Garzon R, Volinia S, Liu CG, Fernandez-Cymering C, Palumbo T, Pichiorri F, Fabbri M, Coombes K, Alder H, Nakamura T, Flomenberg N, Marcucci G, Calin GA, Kornblau SM, Kantarjian H, Bloomfield $\mathrm{CD}$, Andreeff M, Croce CM. MicroRNA signatures associated with cytogenetics and prognosis in acute myeloid leukemia. Blood 2008;111:3183-9

66. Jiang X, Huang H, Li Z, Li Y, Wang X, Gurbuxani S, Chen P, He C, You D, Zhang S, Wang J, Arnovitz S, Elkahloun A, Price C, Hong GM, Ren H, Kunjamma RB, Neilly MB, Matthews JM, Xu M, Larson RA, Le Beau MM, Slany RK, Liu PP, Lu J, Zhang J, He C, Chen J. Blockade of miR-150 maturation by MLL-fusion/MYC/LIN-28 is required for MLL-associated leukemia. Cancer cell 2012;22:524-35.

67. Garzon R, Pichiorri F, Palumbo T, Visentini M, Aqeilan R, Cimmino A, Wang H, Sun H, Volinia S, Alder H, Calin GA, Liu CG, Andreeff M, Croce CM. MicroRNA gene expression during retinoic acidinduced differentiation of human acute promyelocytic leukemia Oncogene 2007;26:4148-57.

68. Zhang H, Luo XQ, Feng DD, Zhang XJ, Wu J, Zheng YS, Chen $\mathrm{X}, \mathrm{Xu} \mathrm{L}$, Chen YQ. Upregulation of microRNA-125b contributes to leukemogenesis and increases drug resistance in pediatric acute promyelocytic leukemia. Mol Cancer 2011;10:108.

69. Becker H, Maharry K, Mrózek K, Volinia S, Eisfeld A, Radmacher MD, Kohlschmidt J, Metzeler KH, Schwind S, Whitman SP, Mendler JH, Wu YZ, Nicolet D, Paschka P, Powell BL, Carter TH, Wetzler M, Kolitz JE, Carroll AJ, Baer MR, Caligiuri MA, Stone RM, Marcucci $\mathrm{G}$, Bloomfield CD. Prognostic gene mutations and distinct gene-and microRNA-expression signatures in acute myeloid leukemia with a sole trisomy 8. Leukemia 2014;28:1754-8.

70. Pileri SA, Ascani S, Cox MC, Campidelli C, Bacci F, Piccioli M, Piccaluga PP, Agostinelli C, Asioli S, Novero D, Bisceglia M, Ponzoni M, Gentile A, Rinaldi P, Franco V, Vincelli D, Pileri A Jr, Gasbarra R, Falini B, Zinzani PL, Baccarani M. Myeloid sarcoma: clinicopathologic, phenotypic and cytogenetic analysis of 92 adult patients. Leukemia 2006;21:340-50.

71. Harris AC, Kitko CL, Couriel DR, Braun TM, Choi SW, Magenau J, Mineishi S, Pawarode A, Yanik G, Levine JE. Extramedullary relapse of acute myeloid leukemia following allogeneic hematopoietic stem cell transplantation: incidence, risk factors and outcomes. Haematologica 2013;98:179-84. 